\title{
Characterization of wound infections among patients injured during the 2011 Libyan conflict
}

\author{
A.A. Dau, ${ }^{1}$ S. Tloba ${ }^{2}$ and M.A. Daw ${ }^{2}$
}

$$
\begin{aligned}
& \text { خصائص عدوى الجروح لدى ذوي الإصابات خلال الصراع في ليبيا عام } 2011
\end{aligned}
$$

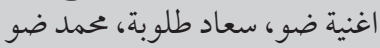

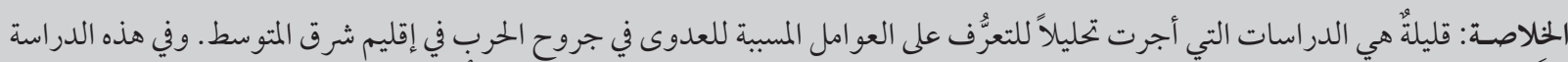

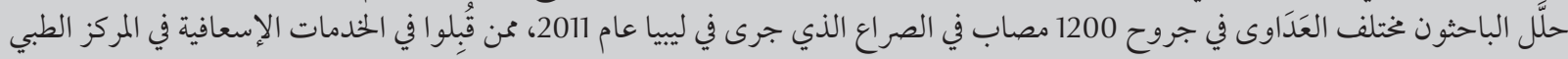

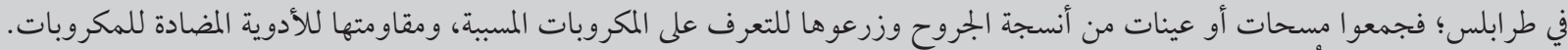

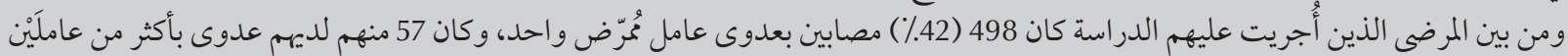

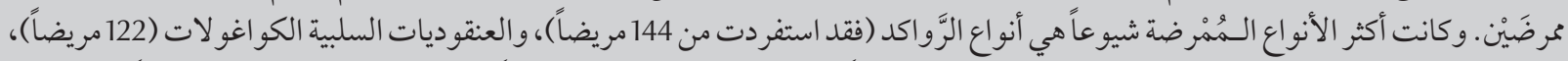

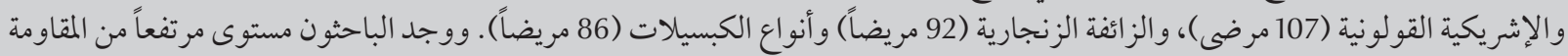

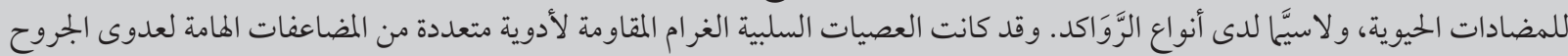

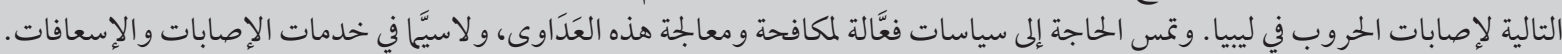

ABSTRACT Few studies have analysed the bacterial pathogenesis of infections associated with war-wound in the Eastern Mediterranean region. We analysed surgical wound infections of 1200 patients injured during the Libyan conflict in 2011 and admitted to the emergency services at Tripoli medical centre. Culture swabs or surgical wound debridement samples were collected and cultures were identified and tested for antimicrobial resistance. Of the 1200 patients studied, 498 (42\%) were infected with at least 1 pathogen and 57 with $>2$ pathogens. The most common species were Acinetobacter spp. (isolated from 144 patients), coagulase-negative staphylococci (122), Escherichia coli (107), Pseudomonas aeruginosa (92) and Klebsiella spp. (86). A high level of resistance to the antibiotics tested was found, especially among Acinetobacter spp. Multi-drug-resistant Gramnegative bacilli were an important complicating factor in wound infections associated with war injuries among injured patients in Libya. Effective policies are needed to control and treat such infections particularly in trauma and emergency services.

Caractérisation des infections de plaies chez les patients blessés pendant le conflit libyen en 2011

RÉSUMÉ Peu d'études ont analysé la pathogénèse bactérienne des infections associées aux plaies de guerre dans la Région de la Méditerranée orientale. Nous avons analysé les infections des plaies après un acte chirurgical chez 1200 patients blessés pendant le conflit libyen en 2011 et admis au service des urgences du centre médical de Tripoli. Des prélèvements par écouvillon ou des échantillons du parage des plaies ont été recueillis puis mis en culture pour identification et analyse à la recherche de résistances aux antimicrobiens. Sur l'ensemble des patients dont les plaies ont été étudiées, 498 étaient porteurs d'une infection (42\%) par au moins un agent pathogène, et 57 par plus de deux agents pathogènes. Les espèces les plus courantes étaient Acintobacter spp. (isolée chez 144 patients), les staphylocoques à coagulase négative (122), Escherichia coli (107), Pseudomonas areuginosa (92) et Klebsiella spp. (86). Un haut niveau de résistance aux antibiotiques testés a été observé, en particulier pour Acinetobacter spp. Les bacilles à Gram-négatif multirésistants représentaient un facteur de complication important pour les infections de plaies associées à des blessures de guerre chez des patients blessés en Libye. Des politiques efficaces sont requises pour lutter contre de telles infections et les traiter, notamment dans les services de traumatologie et des urgences.

${ }^{7}$ Department of Surgery; ${ }^{2}$ Department of Medical Microbiology, Faculty of Medicine, Tripoli, Libya (Correspondence to M.A. Daw: mohamedadaw@gmail.com; mohameddaw@gmail.com).

Received: 01/03/12; accepted: 06/03/12 


\section{Introduction}

Wound infections during wars cause serious morbidity and mortality and have to be treated with great care, particularly by clinical surgeons, who are often the first to treat such cases. The bacterial features of these infections are well-known and the evolution of such infections and the causative pathogens has attracted much attention [1]. Wounding patterns during wars depend on the intensity of fighting and include gunshot bullet wounds, ulceration of vital structures, cavitations and devitalization of tissues and limb amputations. Management of such injuries is no longer the exclusive preserve of military surgeons. Initial measures for treating war injury are similar to those for any severe injury [2].

Despite the clinical complications associated with war-wound infections few studies have analysed their bacterial pathogenesis in the Eastern Mediterranean region, an area that hosts many conflicts [3]. In this study we aimed to analyse the bacterial patterns of wartrauma-associated infections in patients wounded in the conflicts in Libya in 2011, define the factors associated with such infections and determine the antimicrobial resistance patterns of aerobic multi-drug resistant Gram-negative bacilli.

\section{Methods}

\section{Sample}

A total of 1200 injured male patients were admitted to the emergency departments in Tripoli medical centre, Tripoli, Libya, in the 9-month period from March to October 2011. Their ages ranged between 20-55 years. They were brought from different regions of Libya including the Novosa mountains (157 patients), Tripoli/ Zawiya (398 patients), Bani Walid/ Sirte (302 patients), Zlitan/Misrata (236 patients) and other places (107 patients) (Table 1).

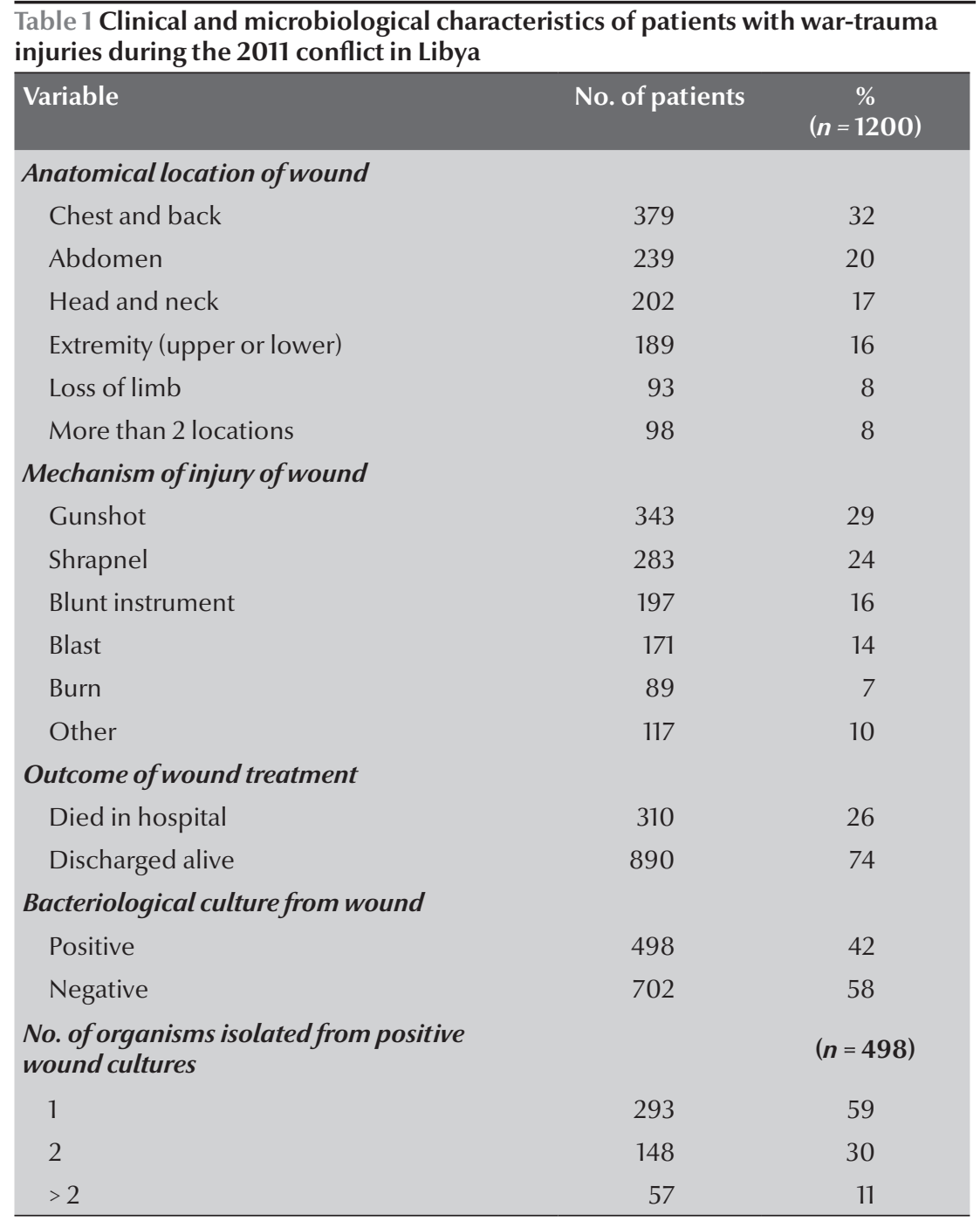

\section{Data collection}

Data collected from each casualty included the mechanism of injury, its anatomical location, previous medical care and antibiotics used. Clinical specimens, which included culture swabs and samples from any existing wound debridements, were collected from the admitted patients.

\section{Bacterial culture techniques}

The specimens were plated onto Columbia blood agar plates, chocolate agar, MacConkey agar plates and into thioglycolate broth. Blood agar and MacConkey agar plates were incubated at $35^{\circ} \mathrm{C}$ in ambient air and chocolate agar was incubated in presence of $5 \% \mathrm{CO}_{2}$ at $35^{\circ} \mathrm{C}$. The thioglycolate broth was Gram-stained as it became turbid. Negative culture plates were left for 5 days, after which negative bacterial cultures were discarded. Each bacterial isolate was biochemically identified using the Analytical Profile Index 20 Enterobacteriaceae (bioMérieux) for lactosefermenting Gram-negative bacilli. Others were identified according the standard microbiological methods established [4].

\section{Antimicrobial susceptibility testing}

Antimicrobial susceptibility testing was determined using the Kirby-Bauer disk diffusion test using National Committee for Clinical Laboratory Standards criteria for each bacterial species [5]. The following antibiotic disks were used for penicillins (ampicillin, amoxicillin, ticarcillin and imipenem), cephalosporins (cefazolin, cefotaxime and ceftazidime), 
aminoglycosides (gentamicin and amikacin) and miscellaneous (ciprofloxacin and tetracycline) and vancomycin (only for Gram-positive cocci).

\section{Results}

\section{Clinical and demographic profile of wounded patients}

The wound injuries of 1200 patients who were brought from different area of Libya were classified as combat-related according to internationally recognized criteria [2].

The mechanisms of wound injuries were as follows: gunshot wounds (29\%), shrapnel wounds (24\%), blunt instrument wounds (16\%), blast wounds (14\%) and burns (7\%) (Table $1)$. The main anatomical sites of the wounds from which swabs for culture were taken were: chest and back (32\%), abdomen (20\%), head and neck (17\%) and extremities (16\%); in 98 patients swabs were taken from more than 2 locations (Table 1). A total of 310 (26\%) of these patients admitted with wound infections died in hospital.

\section{Wound infections}

Positive bacteriological cultures were obtained from the wounds of 498 (42\%) patients. The remaining 702 patients (59\%) had negative bacterial cultures and were classified as uninfected. Both infected and non-infected patients had an average age of about 30 years, ranging from 20-55 years, with no significant difference in age between the infected and uninfected patients.

The injured patients were brought from different geographical zones across Libya. Table 2 shows the distribution of wound-infected and uninfected patients according to the battlefield area and type of battle. The greatest number of infected patients were brought from the Tripoli/Zawiya zone (177 patients), followed by Bani Walid/Sirte (105 patients) and Zlitan/ Misrata (102 patients). Patients bought from Tripoli/Zawiya had the highest rate of infection (44\%) and Bani Walid/Sirte the lowest (35\%). The Novosa mountains area had the highest rate of deaths (39\%). Patients injured in ground battles (i.e. those were brought from the rebel fighting areas) had a higher rate of infection (43\%) than those wounded by airstrikes (i.e. those brought from army compounds where there was no fighting on the ground) (36\%) (Table 2).

\section{Organisms cultured and susceptibility patterns}

Of the 498 patients with positive bacterial cultures, 293 (59\%) had a single organism isolated, 148 (30\%) had 2 organisms and 57 (11\%) had more than 2 pathogens.

The most common organism cultured from wounded patients was Gram-negative bacilli, which included Acinetobacter spp. in 144 patients, Escherichia coli from 107 patients, Pseudomonas spp. from 92 patients, Klebsiella spp. from 86 patients, while other Gram-negative species were cultured from 157 patients. Gram-positive cocci were cultured from 178 patients, mainly coagulasenegative staphylococci isolated from 122 patients, while other Gram-positive bacteria were cultured from 56 patients.

The antimicrobial susceptibility patterns of these organisms are shown in Table 3. Acinetobacter spp. were the most resistant pathogen. Other isolated Gram-negative bacteria showed great resistance to 3rd-generation cephalosporins and aminoglycosides, apart from amikacin. However, P. aeruginosa was quite susceptible to commonly used antipseudomonal therapy particularly carbapenems. Coagulase-negative staphylococci were found to be sensitive to all the antibiotics tested particularly gentamicin and vancomycin.

\section{Discussion}

Wound infections associated with war injuries have changed over the last

\begin{tabular}{|c|c|c|c|c|c|c|c|}
\hline \multirow[t]{2}{*}{ Variable } & \multicolumn{2}{|c|}{$\begin{array}{l}\text { Infected } \\
(n=498)\end{array}$} & \multicolumn{2}{|c|}{$\begin{array}{l}\text { Uninfected } \\
(n=702)\end{array}$} & \multicolumn{2}{|c|}{$\begin{array}{c}\text { Died } \\
(n=310)\end{array}$} & \multirow{2}{*}{$\begin{array}{c}\begin{array}{c}\text { Total } \\
(n=1200) \\
\text { No. }\end{array} \\
\text {. }\end{array}$} \\
\hline & No. & $\%$ & No. & $\%$ & No. & $\%$ & \\
\hline \multicolumn{8}{|l|}{ Battlefield area } \\
\hline Tripoli/Zawiya & 177 & 44 & 221 & 56 & 93 & 23 & 398 \\
\hline Novosa mountains & 68 & 43 & 89 & 57 & 61 & 39 & 157 \\
\hline Bani Walid/Sirte & 105 & 35 & 197 & 65 & 79 & 26 & 302 \\
\hline Zlitan/Misrata & 102 & 43 & 134 & 57 & 72 & 31 & 236 \\
\hline Other places & 46 & 43 & 61 & 57 & 17 & 16 & 107 \\
\hline \multicolumn{8}{|l|}{ Type of battle } \\
\hline Ground battles & 391 & 43 & 508 & 57 & 127 & 14 & 899 \\
\hline Airforce strikes & 107 & 36 & 194 & 64 & 183 & 61 & 301 \\
\hline
\end{tabular}

$n=$ number of patients. 


\begin{tabular}{|c|c|c|c|c|c|c|c|c|c|c|}
\hline \multirow[t]{2}{*}{$\begin{array}{l}\text { Antimicrobials } \\
\text { tested }\end{array}$} & \multicolumn{2}{|c|}{$\begin{array}{l}\text { Escherichia coli } \\
\qquad(n=107)\end{array}$} & \multicolumn{2}{|c|}{$\begin{array}{l}\text { Klebsiella spp. } \\
\quad(n=86)\end{array}$} & \multicolumn{2}{|c|}{$\begin{array}{l}\text { Acinetobacter spp. } \\
\qquad(n=144)\end{array}$} & \multicolumn{2}{|c|}{$\begin{array}{l}\text { Pseudomonas spp. } \\
\qquad(n=92)\end{array}$} & \multicolumn{2}{|c|}{$\begin{array}{c}\text { Coagulase- } \\
\text { negative } \\
\text { staphylococci } \\
(n=122)\end{array}$} \\
\hline & No. & $\%$ & No. & $\%$ & No. & $\%$ & No. & $\%$ & No. & $\%$ \\
\hline \multicolumn{11}{|l|}{ Penicillins } \\
\hline Ampicillin & 25 & 23 & 10 & 12 & 4 & 3 & - & - & 0 & 0 \\
\hline Oxacillin & - & - & - & - & - & - & - & - & 20 & 16 \\
\hline Ticarcillin & 0 & 0 & 0 & 0 & 0 & 0 & 74 & 80 & - & - \\
\hline Imipenem & 107 & 100 & 86 & 100 & 144 & 100 & 90 & 98 & - & - \\
\hline \multicolumn{11}{|l|}{ Cephalosporins } \\
\hline Cefazolin & 45 & 42 & 20 & 23 & 0 & 0 & 0 & 0 & - & - \\
\hline Cefotaxime & 27 & 25 & 21 & 24 & 9 & 6 & 0 & 0 & - & - \\
\hline Ceftazidime & 75 & 70 & 73 & 85 & 0 & 0 & 85 & 92 & - & - \\
\hline \multicolumn{11}{|l|}{ Aminoglycosides } \\
\hline Gentamicin & 47 & 44 & 51 & 59 & 46 & 32 & 47 & 51 & 70 & 57 \\
\hline Amikacin & 107 & 100 & 63 & 73 & 20 & 14 & 82 & 89 & - & - \\
\hline \multicolumn{11}{|l|}{ Miscellaneous } \\
\hline Ciprofloxacin & 90 & 84 & 80 & 93 & 101 & 70 & 87 & 95 & 50 & 41 \\
\hline Tetracycline & - & - & - & - & - & - & - & - & 115 & 94 \\
\hline Vancomycin & - & - & - & - & - & - & - & - & 120 & 98 \\
\hline
\end{tabular}

Other Gram-negative bacilli ( $n=157$ isolates); other Gram-positive bacteria $(n=56)$.

$n=$ number of isolates tested; zero $(0)$ indicates no bacteria cultures; dash (-) indicates not applicable.

century, not only in the pattern of the causative organisms and the antimicrobials used to tackle such serious infection but also in the physician's approach to handling them. Formerly the bacteriological characterization of war-associated infections was based on the colour of the discharge and the smell of the wound which was associated with anaerobic bacteria particularly Clostridium spp. [6]. Such infection was associated with a high rate of morbidity and mortality among the infected individuals. This has changed with the introduction of antibiotics and modern surgical management of wounds. This has resulted in the diminution of Gram-positive bacteria and emergence of more resistant ones particularly the aerobic and facultative anaerobic Gram-negative bacilli $[3,7,8]$. Our study in Libya showed that the infection rate among patients with war-associated infection was $42 \%$ with no variation according to the different regions where the injured patients came from. The infections were mainly caused by multidrug-resistant (MDR) Gram-negative bacilli.

Gunshot wounds result in gross tissue destruction that is an excellent medium for infection. In this study direct gunshot, blast, blunt instrument and shrapnel wounds were the most common injuries. Such results are in agreement with other data collected from war conflicts in Vietnam, Somalia and Iraq $[9,10]$.

MDR Gram-negative bacilli are known to be a major cause of nosocomial infection particularly in wound infections $[3,10]$. This is more obvious in war situations. However, MDR P. aeruginosa, extended-spectrum betalactamase-producing Klebsiella and Acinetobacter spp. were isolated extensively from wound infections during the Iraqi war $[4,9]$. In the present study, MDR Gram-negative bacilli were the major bacteria associated with wound infections in injured patients in Libya. MDR Acinetobacter spp. isolates were the most common pathogen, accounting for 144 of the isolates cultured, followed by E. coli, P. aeruginosa and Klebsiella spp. The incidence of MDR Gram-negative bacilli and their rate of antibiotic resistance were higher in this study compared with similar studies carried in different geographical regions $[6,8,11]$. This, however, may suggest different ecosystems and bacteria involved in these infections.

Gram-positive bacteria have been known to be involved in wound injury and many studies have reported this [12]. In our study 122 coagulase-negative staphylococci isolates and another 56 miscellaneous Gram-positive bacteria were cultured from the wounded patients and sometimes were found to be co-pathogens with MDR Gram-negative bacilli. All of them were sensitive to all the antimicrobials tested except oxacillin and ampicillin. This may indicate 
they were skin-commensal pathogens which are considered to be of low virulence and pathogenicity [13].

The patients in this study were often wounded far from hospital and evacuated under escalating conflict conditions with contaminated wounds and diminished vascular function. Patients with soft tissue injuries and blast, gunshot and burn injuries had open wounds that could easily have been contaminated with soil, dust and contact with the hands of the people who evacuated them. The bacteria may have colonized wounds at the time of injury or as a result of personnel contact during evacuation or inside the hospital. Similar results were reported from other investigators for victims of the tsunami in Bali as well as victims of the Bosnian and Iraqi conflicts $[14,15]$. This indicates that the source of acquisition of these organisms may be environmental from the battleground or endogenously from the patient him/herself.

The use of antimicrobials in the treatment of surgical wound infections is still disputed. Antibiotics may affect the wound flora and thus enhance the more resistant bacteria. Furthermore, it is not clear which is the most appropriate antimicrobial to use in these circumstances: a narrow-spectrum one that covers a specific type of bacteria or a broad-spectrum one [16]. However, in certain conditions, such as unconscious or shocked patients and abdominal surgery, antibiotics have to be used. The antimicrobial resistance patterns in this study can be used to guide their empirical use in cases of pyrexia, shock or intensive soft tissue injury.

The pathogenicity of the bacteria plays an important role in wound infection, which might be related to the virulence factors of the pathogens themselves or existence of co-pathogens [17]. In this study $59 \%$ of the patients had a single pathogen, $30 \%$ showed 2 different isolates and $11 \%$ showed 3 or more isolates. This may suggest the role of co-pathogens in the development of necrotizing war trauma-related infection, particularly in Acinetobacter spp., which has been indicated by other studies $[3,18]$. Further studies are needed to determine the virulence factors and mechanism of resistance of such pathogens.

Our study focused on Gram-negative bacilli as most of the patients studied had required immediate evacuation and undergone immediate surgical debridement. This was likely to have minimized the role of anaerobic infection in these patients. Furthermore, anaerobic bacteria are uncommonly recognized as a cause of wound war infections except in the Korean war [11]. This highlights the importance of the present study, which is one of the few studies in Arab countries that have documented the patterns of war-wound infections and characterized the causative agents of these injuries. Furthermore, the detection of highly resistant bacteria, such as Acinetobacterspp., P. aeruginosa, Klebsiella spp. and E. coli, mandates a change in the management of surgical wounds and infection control measures, as well as specific guidelines for the use of antimicrobials in all hospital settings and emergency trauma services in Libya $[3,19,20]$.

\section{References}

1. Eardley WG et al. Infection in conflict wounded. Philosophical Transactions of the Royal Society of London. Series B, Biological Sciences, 2011, 366:204-218.

2. Hospenthal DR et al. Guidelines for the prevention of infections associated with combat-related injuries: 2011 update: endorsed by the Infectious Diseases Society of America and the Surgical Infection Society. Journal of Trauma, 2011, 71(Suppl. 2):S210-S234.

3. Daw MA, Dau AA, Elasifer H, Tloba S. Emergence of multiresistant Acinetobacter baumannii among Libyan military personnel during recent Libyan conflict. In: Proceedings of the 22nd European Congress of Clinical Microbiology and Infectious Diseases, London, 31 March to 3 April, 2012.

4. Performance standards for antimicrobial disk susceptibility tests: approved standard, 7th ed. Wayne, Pennsylvania, National Committee for Clinical Laboratory Standards, 2000.

5. Bauer AW et al. Antibiotic susceptibility testing by a standardized single disk method. American Journal of Clinical Pathology, 1966, 45:493-496.

6. Manring MM et al. Treatment of war wounds: a historical review. Clinical Orthopaedics and Related Research, 2009, 467:2168-2191.

7. Martin GJ et al.; Prevention of Combat-Related Infections Guidelines Panel. Prevention of infections associated with combat-related thoracic and abdominal cavity injuries. Journal of Trauma, 2011, 71(2 Suppl. 2):S270-281.
8. Scott PT et al. Acinetobacter baumanii infections among patients at military facilities treating injured U.S. service members, 2002-2004. Morbidity and Mortality Weekly Report, 2004, 53:1063-1066.

9. Centers for Disease Control and Prevention. Acinetobacter baumannii infections among patients at military medical facilities treating injured U.S. service members, 2002-2004. Morbidity and Mortality Weekly Review, 2004, 53:1063-1066.

10. Mabry RL et al. United States Army Rangers in Somalia: an analysis of combat casualties on an urban battlefield. Journal of Trauma, 2000, 49:515-528.

11. Klein RS, Berger SA, Yekutiel P. Wound infection during the Yom Kippur War: observations concerning antibiotic prophylaxis and therapy. Annals of Surgery, 1975, 182:15-21.

12. Ellis MW et al. Natural history of community-acquired methicillin-resistant Staphylococcus aureus colonization and infection in soldiers. Clinical Infectious Diseases, 2004, 39:971-979.

13. Lolans $\mathrm{K}$ et al. Prevention and management of infections associated with combat-related head and neck injuries. Journal of Trauma, 2008, 64:S265-S276.

14. Heath $\mathrm{CH}$ et al. A review of the Royal Perth Hospital Bali experience: an infection control perspective. Australian Infection Control, 2003, 8:43-54.

15. Maegele $\mathrm{M}$ et al. The long-distance tertiary air transfer and care of tsunami victims: injury pattern and microbiological and psychological aspects. Critical Care Medicine, 2005, 33:1136-1140. 
16. Hayda R, Harris RM, Bass CD. Blast injury research: modeling injury effects of landmines, bullets, and bombs. Clinical Orthopaedics and Related Research, 2004, 422:97-108.

17. Sebeny PJ et al. Acinetobacter baumannii skin and soft-tissue infection associated with war trauma. Clinical Infectious Diseases, 2011, 47(4):444-449.

18. Moultrie D, Hawker J, Cole S. Factors associated with multidrug-resistant Acinetobacter transmission: an integrative review of the literature. AORN Journal, 2011, 94(1):27-36.
19. Daw MA, Drah AM. Antibiotic resistance: prospects for the new millennium. Journal of Chemotherapy (Florence, Italy), 2001, 13:587-594.

20. Hospenthal DR et al.; Prevention of Combat-Related Infections Guidelines Panel. Infection prevention and control in deployed military medical treatment facilities. Journal of Trauma, 2011, 71(Suppl. 2):S290-S298.

\section{Prevention and management of wound infection}

Open injuries have a potential for serious bacterial wound infections, including gas gangrene and tetanus, and these in turn may lead to long term disabilities, chronic wound or bone infection, and death. Wound infection is particularly of concern when injured patients present late for definitive care, or in disasters where large numbers of injured survivors exceed available trauma care capacity. Appropriate management of injuries is important to reduce the likelihood of wound infections. The document Prevention and management of wound infection provides core principles and protocols for appropriate prevention and management of infected wounds.

This document is available at: http://www.who.int/hac/techguidance/tools/guidelines_prevention_and_ management_wound_infection.pdf 